\title{
Morphology Reveals the Unexpected Cryptic Diversity in Ceratophyllus gallinae (Schrank, 1803) Infested Cyanistes caeruleus Linnaeus, 1758 Nest Boxes
}

\author{
Olga Pawełczyk ${ }^{1}$ ([) $\cdot$ Tomasz Postawa $^{2}$ (I) $\cdot$ Marian Blaski $^{3} \cdot$ Krzysztof Solarz $^{1}$ (i)
}

Received: 6 June 2019 / Accepted: 29 May 2020 / Published online: 8 June 2020

(c) The Author(s) 2020

\begin{abstract}
Purpose The main aim of our study was to examine morphological differentiation between and within sex of hen fleasCeratophyllus gallinae (Schrank, 1803) population collected from Eurasian blue tit (Cyanistes caeruleus Linnaeus, 1758), inhabiting nest boxes and to determine the morphological parameters differentiating this population.

Methods A total of 296 fleas were collected (148 females and 148 males), determined to species and sex, then the following characters were measured in each of the examined fleas: body length, body width, length of head, width of head, length of comb, height of comb, length of tarsus, length of thorax and length of abdomen.

Results The comparison of body size showed the presence of two groups among female and male life forms of the hen flea, which mostly differed in length of abdomen, whereas the length of head and tarsus III were less variable.

Conclusion Till now, the only certain information is the presence of two adult life forms of $C$. gallinae. The genesis of their creation is still unknown and we are not able to identify the mechanism responsible for the morphological differentiation of fleas collected from the same host. In order to find answer to this question, future research in the field of molecular taxonomy is required.
\end{abstract}

Keywords Body size variability $\cdot$ Ceratophyllus gallinae $\cdot$ Fleas $\cdot$ Morphological diversity $\cdot$ Sexual size dimorphism

\section{Introduction}

Olga Pawełczyk

olga.pawelczyk@sum.edu.pl

Tomasz Postawa

postawa@isez.pan.krakow.pl

Marian Blaski

marian.blaski@us.edu.pl

Krzysztof Solarz

solarzk@sum.edu.pl

1 Department of Parasitology, Faculty of Pharmaceutical Sciences in Sosnowiec, Medical University of Silesia, Jedności 8, 41-200 Sosnowiec, Poland

2 Department of Vertebrate Zoology, Institute of Systematics and Evolution of Animals of the Polish Academy of Sciences, Sławkowska 17, 31-016 Kraków, Poland

3 Department of Zoology, Faculty of Biology and Environmental Protection, University of Silesia, Bankowa 9, 40-007 Katowice, Poland
Females and males of nearly all arthropods differ in their body size. This phenomenon is also widespread among insects and is called a sexual size dimorphism (SSD). SSD likely appears when growth patterns of females and males of the same species differ in their sensitivity to environmental conditions [1]. In addition, the larger size of body and particular body parts is more desirable among insects. The main reasons of larger size selection may be the increase of mating success in males and fecundity of females, what allows to produce a bigger offspring [1-8]. Moreover, seasonal changes of environment and presence of many differences between life forms during arthropods' life cycle can cause the phenotype variation among adult individuals $[8,9]$. They may differ in shape, behavior and their response to environmental factors. Heteromorphism-different forms at various periods of the male life cycle, is a phenomenon known among Acari, including groups of mites such as Astigmata and Prostigmata [10-14]. It is often related to sexual behavior or male reproductive strategy and can lead to increased 
reproductive success among heteromorphic males $[11,13]$. In turn, gynopolymorphism (sex carrying the polymorphism in female) was reported among representatives of order Diptera (Drosophila melanogaster), Odonata (Coenagrion, Enallagma, Ischnura) and many species of Lepidoptera (e.g. from Colias genus) [15-17].

Variability of ectoparasite population is caused by degree of host specificity, the mode of parasite transmission and the ability for adaptive phenotypic plasticity $[18,19]$. Fleas are obligatory external parasites of birds and mammals, thus their more pronounced morphological variability can depend on their type of the host and the host living environment. Individual morphological characteristics of fleas can be a result of host migration, its diet or condition [9, 20]. External parasites are also subjected to a strong selection, which can lead to convergent evolved phenotypes among one or more species. Furthermore, a strong selective pressure on loci, which controls morphological differences in organisms, can be caused by genetic isolation of the population of each host and the adaptation to a particular host [19,21].

Fleas demonstrate strong female-biased SSD, what is a common trend among other groups of arthropods. Sexual size dimorphism decreases in larger species [22]. Furthermore, fleas do not demonstrate strong stable selection or strong constraints on female size. For example, egg production and egg size in fleas are reported to be independent of body size [23, 24], but were explained well by the patterns of relationships with their hosts. A high morphological variability between males and females was reported in Ceratophyllus hirundinis (Curtis 1826) collected from nests of Delichon urbica (Linnaeus 1758) (Upper Silesia, Poland) [25]. Similar pattern was observed in a morphological variability of Ceratophyllus gallinae (Schrank 1803) collected from Cyanistes caeruleus Linnaeus 1758 (before Parus caeruleus) nests. These results demonstrate that both males and females manifested a high morphological variability [9].

Main aims of our study are to examine the morphological differentiation between and within sex of population collected from Eurasian Blue Tits $C$. caeruleus inhabiting nest boxes and to determine morphological parameters differentiating this population.

\section{Materials and Methods}

\section{Ectoparasite Species}

The hen flea $C$. gallinae is a common species in Europe, North America and New Zealand, which has an extremely wide range of parasitizing hosts including 72 wild birds' species and about 15 species of mammals. This flea regularly invades poultry and could cause the fatal iron deficiency, anemia and allergic dermatitis of fowls [26-28]. To the main hosts of $C$. gallinae belong blue (C. caeruleus) and great (Parus major) tits [28, 29]. Most of $C$. gallinae adults overwintering in the cocoons and occur in relatively large numbers in nests of their hosts during winter. In contrast to the birds breeding season, when fleas disperse among birds generations $[30,31]$. C. gallinae fleas often occur with another flea species-Dasypsyllus g. gallinulae (Dale, 1878) or with blow flies of the genus Protocalliphora (Diptera: Calliphoridae) in the same nest, which can affect bird reproductive performance [31, 32].

\section{Host Species}

In this study, fleas were collected from the blue tits $C$. caeruleus nest boxes. Blue tits are common European passerine birds, which build their nests in natural tree-holes and often inhabit nest boxes. Each spring, females lay around 10 eggs, which are incubated and hatch 2 weeks later. $C$. gallinae infestation in nests and nest boxes significantly affects the behavior of bird females [28, 33, 34].

\section{Data Collection and Material Preparation}

The hen fleas $C$. gallinae were collected in the period between 1998-2003 from blue tits (C. caeruleus) nest boxes, which occurred in Panewniki Forestry Commission, land in the vicinity of Ruda Ślaska (Upper Silesia, in the Southern Poland). Nest boxes were placed in deciduous forest of Panewniki Forestry Commission, and systematically examined throughout the year except for May, when tits lay eggs and nestlings hatch. Nest boxes and fleas were not collected at that time, in order to protect birds. All fleas were isolated from the nests and litter collected from nest boxes by using Tullgren apparatus. All specimens were preserved in 70\% ethyl alcohol and preparated. Fleas were placed on microscopic permanent slides in Berlese solution. C. gallinae were determined according to Skuratowicz key [26]. All specimens were deposited in Department of Zoology at the University of Silesia (Katowice, Poland). A total of 296 fleas were collected, including 148 females and 148 males. To determine fleas to species, sex and to measure morphological features optical microscopy were used (Olympus $\mathrm{CH} 40$ ). The following characters were measured in each of the examined fleas: body length, body width, length of head, width of head, length of comb, height of comb, length of tarsus, length of thorax and length of abdomen. The examined material has been clustered into males and females, and after preliminary morphometric analysis into males and females with a typical and smaller body size for examined flea species. SSD-related traits are length and height of comb. Moreover, the body length, body width, length of thorax, length of abdomen, length of head and width of head could be determined by SSD. These six features could be 
also determined by the nutritional status of individual. The length of tarsus depends on physiological differences, such as jumping performance [35].

\section{Data Analysis}

Data were analyzed in several steps. Initially, sex determination and morphological measurements specimens were performed. Due to presence of noticeable differences in their size: normal type and smaller type, specimens were preliminary divided into two subgroups. The "small" and "typical" forms were previously marked by Blaski et al. [9]. The "typical" forms had bigger size of thorax and abdomen than "smaller" forms, while size of head and tarsus in both were similar. To test whether this classification is valid, morphometric data (continuous variables) were subjected to hierarchical cluster analysis with the Ward's minimum variance method (clustering tree: $R$ package pvclust) [36]. Obtained separate clusters with addition of sex effect were analyzed using a two-way Multivariate Analysis of Variance (MANOVA). Post hoc comparisons were conducted to test for differences between the two forms and sex in each morphological measurement. We compared variation within and between obtained groups using MANOVA with fixed factor: sex and form of flea. Analyses were performed using R ( $\mathrm{R}$ software v. 3.4.3) [37]. In all tests, values of $p<0.05$ were considered significant.

\section{Results}

Hierarchical clustering analysis based on nine morphometrical body size parameters of $C$. gallinae $(n=296)$ individuals tightly corresponded with the pre-selection determination and consists from two subgroups. Cluster 5 corresponded with smaller form (males $=90$, females $=57$ ), while cluster 6-with normal size form (males $=58$, females $=91$ ) (Fig. 1). The two groups indicated by cluster analysis were completely identical to the preliminary classification in "small" and "typical". Remaining clusters: 1, 2, 3 and 4 were not clearly separated based on sex, but rather exhibited intermorphotype variability, therefore were excluded from further analyses.

This differentiation was supported by a multivariate analysis of variance (MANOVA). The two main clusters (5 and 6) differed significantly in analyzed morphological traits of the body size (MANOVA, Wilk's $\lambda=0.163$, d.f. $=9,284, F=161.0, p<0.0001)$, the differences were also found between sexes (Wilk's $\lambda=0.470, d . f .=9,284$, $F=35.7, p<0.0001)$. The interaction and sex clusters were significantly different (Wilk's $\lambda=0.902$, d.f. $=9,284$, $F=3.40, p=0.0005$ ). Variances were explained by length of abdomen, body length and body width, less by length

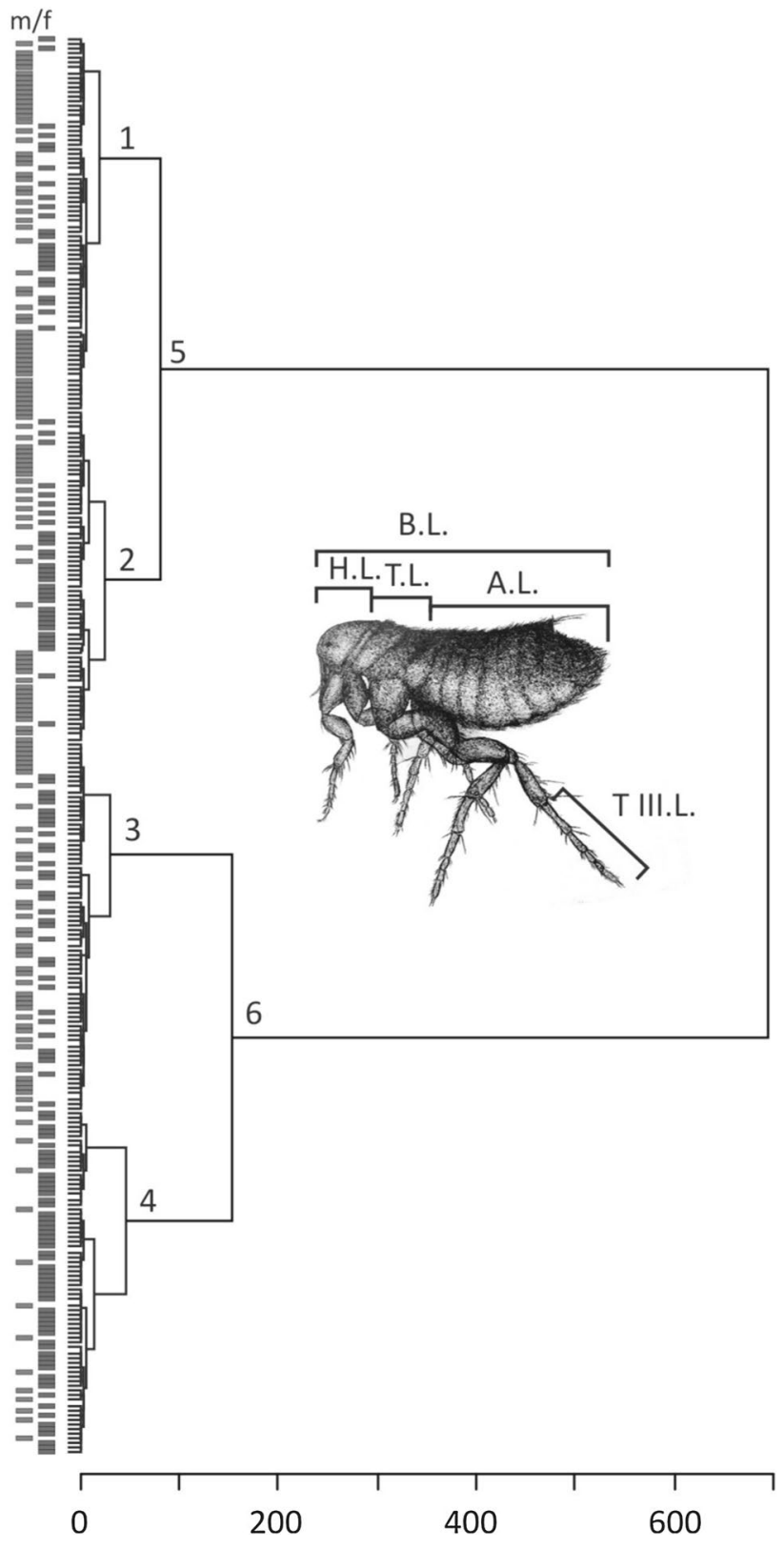

Fig. 1 Hierarchical cluster analysis (Ward's methods) of flea specimens $(n=296)$ using morphometrics traits. B.L. body length; H.L. head length; T.L. thorax length; A.L. abdomen length; T III. L. tarsus III length, $m$ males, $f$ females

of thorax, width of head, height of comb, and in minor degree by length of tarsus, length of comb and length of head (Table 1).

Size differences between the forms are determined by all nine analyzed parameters, the most divergent measurement: length of abdomen and body length, following length of thorax, body width, with minor differences in remaining parameters: width of head, height and length of comb, length of tarsus and length of head (Table 1). Sex differences (within forms) were smaller, and accounted from 1 
Table 1 Results of the subsequent analysis of variance (two-way ANOVA-s) showing the morphometrical traits distinguishing the "typical" and the "small" form of Ceratophyllus gallinae

\begin{tabular}{|c|c|c|c|c|}
\hline Character & Factor & d.f & $F$ & $p$ \\
\hline Length of body & $\begin{array}{l}\text { Cluster } \\
\text { Sex } \\
\text { Cluster } \times \text { sex } \\
\text { Residuals } \\
R^{2} \text { adjusted }=76.6 \%\end{array}$ & $\begin{array}{r}1 \\
1 \\
1 \\
292\end{array}$ & $\begin{array}{r}927.1 \\
29.2 \\
10.0\end{array}$ & $\begin{array}{c}<0.00001 * * * * \\
<0.00001 * * * \\
0.002 * *\end{array}$ \\
\hline Width of body & $\begin{array}{l}\text { Cluster } \\
\text { Sex } \\
\text { Cluster } \times \text { sex } \\
\text { Residuals } \\
R^{2} \text { adjusted }=65.0 \%\end{array}$ & $\begin{array}{r}1 \\
1 \\
1 \\
292\end{array}$ & $\begin{array}{r}442.5 \\
106.3 \\
2.93\end{array}$ & $\begin{aligned} &<0.00001 * * * \\
&<0.00001 * * * \\
& 0.09\end{aligned}$ \\
\hline Length of head & $\begin{array}{l}\text { Cluster } \\
\text { Sex } \\
\text { Cluster } \times \text { sex } \\
\text { Residuals } \\
R^{2} \text { adjusted }=43.4 \%\end{array}$ & $\begin{array}{r}1 \\
1 \\
1 \\
292\end{array}$ & $\begin{array}{l}7.35 \\
1.36 \\
7.68\end{array}$ & $\begin{array}{l}0.007 * * \\
0.245 \\
0.006 * *\end{array}$ \\
\hline Width of head & $\begin{array}{l}\text { Cluster } \\
\text { Sex } \\
\text { Cluster } \times \text { sex } \\
\text { Residuals } \\
R^{2} \text { adjusted }=45.6 \%\end{array}$ & $\begin{array}{r}1 \\
1 \\
1 \\
292\end{array}$ & $\begin{array}{r}79.4 \\
171.1 \\
0.35\end{array}$ & $\begin{aligned} &<0.00001 * * * \\
&<0.00001 * * * \\
& 0.56\end{aligned}$ \\
\hline Length of pronotal comb (ctenidium) & $\begin{array}{l}\text { Cluster } \\
\text { Sex } \\
\text { Cluster } \times \text { sex } \\
\text { Residuals } \\
R^{2} \text { adjusted }=19.4 \%\end{array}$ & $\begin{array}{r}1 \\
1 \\
1 \\
292\end{array}$ & $\begin{array}{c}23.04 \\
50.3 \\
0.67\end{array}$ & $\begin{aligned} &<0.00001 * * * \\
&<0.00001 * * * \\
& 0.41\end{aligned}$ \\
\hline Height of pronotal comb (ctenidium) & $\begin{array}{l}\text { Cluster } \\
\text { Sex } \\
\text { Cluster } \times \text { sex } \\
\text { Residuals } \\
R^{2} \text { adjusted }=34.1 \%\end{array}$ & $\begin{array}{r}1 \\
1 \\
1 \\
292\end{array}$ & $\begin{array}{r}58.3 \\
97.0 \\
0.52\end{array}$ & $\begin{aligned} &<0.00001 * * * \\
&<0.00001 * * * \\
& 0.47\end{aligned}$ \\
\hline Length of tarsus III & $\begin{array}{l}\text { Cluster } \\
\text { Sex } \\
\text { Cluster } \times \text { sex } \\
\text { Residuals } \\
R^{2} \text { adjusted }=29.5 \%\end{array}$ & $\begin{array}{r}1 \\
1 \\
1 \\
292\end{array}$ & $\begin{array}{l}56.3 \\
69.8 \\
0.294\end{array}$ & $\begin{aligned} &<0.00001 * * * \\
&<0.00001 * * * \\
& 0.56\end{aligned}$ \\
\hline Length of thorax & $\begin{array}{l}\text { Cluster } \\
\text { Sex } \\
\text { Cluster } \times \text { sex } \\
\text { Residuals } \\
R^{2} \text { adjusted }=47.0 \%\end{array}$ & $\begin{array}{r}1 \\
1 \\
1 \\
292\end{array}$ & $\begin{array}{l}199.3 \\
66.2 \\
0.342\end{array}$ & $\begin{aligned} &<0.00001 * * * \\
&<0.00001 * * * \\
& 0.56\end{aligned}$ \\
\hline Length of abdomen & $\begin{array}{l}\text { Cluster } \\
\text { Sex } \\
\text { Cluster } \times \text { sex } \\
\text { Residuals } \\
R^{2} \text { adjusted }=79.2 \%\end{array}$ & $\begin{array}{r}1 \\
1 \\
1 \\
292\end{array}$ & $\begin{array}{r}1091.8 \\
14.6 \\
16.7\end{array}$ & $\begin{array}{r}<0.00001 * * * \\
0.0002 * * * \\
0.00006 * * *\end{array}$ \\
\hline
\end{tabular}

d.f. degrees of freedom

$p$ statistical significance $(* p<0.05, * * p<0.01, * * * p<0.001)$ 
to almost $18 \%$. Among eight analyzed parameters the most differentiate were width of head, length of thorax, height and length of comb, body width and length of tarsus III. In turn, minor differences were found in body length, length of abdomen and length of head. Interaction cluster and sex, which indicated differences between clusters in size alter with sex, were noted in three analyzed parameters, such as body length, body width and length of abdomen (Table 2). Therefore, the differences between clusters (forms) appeared to be homogeneous. The mutual dependencies of abdomen length and body width of examined $C$. gallinae individuals show a positive correlation (Fig. 2).

\section{Discussion}

This study highlights the presence of differences both in SSD and various morphotypes ("small" and "typical") among males and females of examined C. gallinae population. Theory would predict that in organisms often exposed to variation in food resource during development, adaptive plasticity would evolve to minimize such effects [38, 39]. This prediction is also supported by the observation

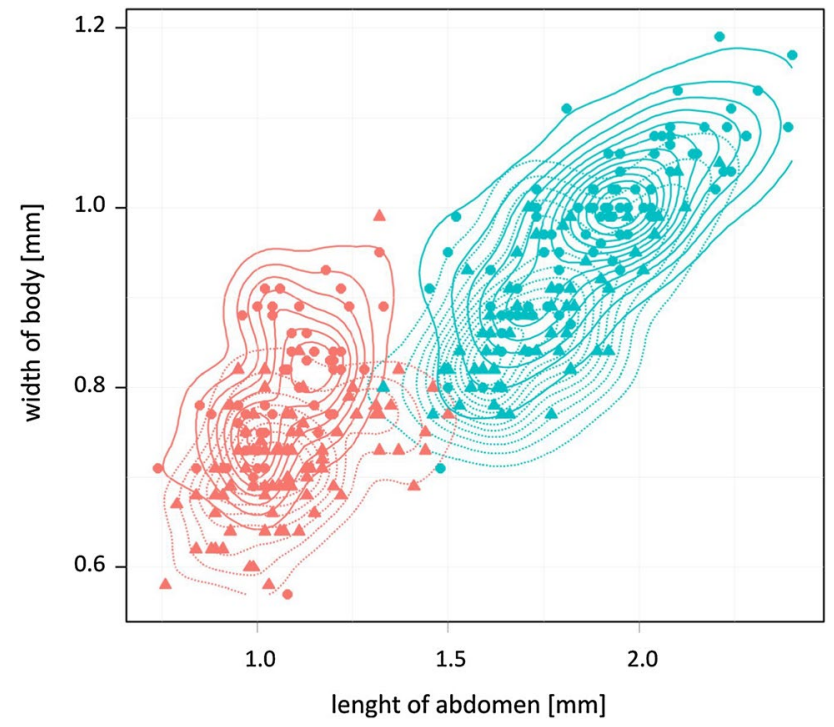

Fig. 2 Scatter plot of abdomen length against body width of Ceratophyllus gallinae. Triangle-males, filled circle-females; Density lines: turquoise — "typical” form, orange_- "small” form, solid linefemales, dashed lines-males

Table 2 Mean $( \pm \mathrm{SD})$ and confidence interval ( $\pm 95 \%)$ of body size two population of adult hen flea Ceratophyllus gallinae: "typical and, small" form. Two-way ANOVA was used to evaluate statistically significant differences between the two clusters and their sex

\begin{tabular}{|c|c|c|c|c|c|c|c|c|c|}
\hline \multirow{2}{*}{$\begin{array}{l}\text { Males } \\
\text { Character }\end{array}$} & \multicolumn{3}{|c|}{ Typical form $(n=58)$} & \multicolumn{3}{|c|}{ Small form $(n=90)$} & \multirow[b]{2}{*}{$F$} & \multirow[b]{2}{*}{$p$} & \\
\hline & Mean & SD & $\pm 95 \%$ & Mean & SD & $\pm 95 \%$ & & & \\
\hline Body length & 2.54 & 0.235 & $2.48-2.60$ & 1.77 & 0.174 & $1.731-1.804$ & 375.1 & $<0.00001$ & $* * *$ \\
\hline Body width & 0.88 & 0.075 & $0.86-0.90$ & 0.72 & 0.064 & $0.704-0.731$ & 154.2 & $<0.00001$ & $* * *$ \\
\hline Head length & 0.35 & 0.029 & $0.35-0.36$ & 0.34 & 0.031 & $0.331-0.344$ & 16.4 & 0.0001 & $* * *$ \\
\hline Head width & 0.25 & 0.036 & $0.24-0.26$ & 0.23 & 0.027 & $0.225-0.237$ & 15.5 & 0.0001 & $* * *$ \\
\hline Pronotal comb length & 0.083 & 0.013 & $0.08-0.09$ & 0.078 & 0.013 & $0.075-0.080$ & 2.64 & 0.106 & $\mathrm{~ns}$ \\
\hline Pronotal comb height & 0.23 & 0.027 & $0.22-0.23$ & 0.21 & 0.027 & $0.202-0.213$ & 10.5 & 0.0015 & $* *$ \\
\hline Tarsus III length & 0.80 & 0.062 & $0.79-0.82$ & 0.75 & 0.058 & $0.741-0.766$ & 15.6 & 0.0001 & $* * *$ \\
\hline Thorax length & 0.43 & 0.061 & $0.41-0.44$ & 0.34 & 0.046 & $0.327-0.346$ & 77.1 & $<0.00001$ & $* * *$ \\
\hline Abdomen length & 1.74 & 0.178 & $1.69-1.79$ & 1.08 & 0.163 & $1.048-1.117$ & 376.4 & $<0.00001$ & $* * *$ \\
\hline \multirow{2}{*}{$\begin{array}{l}\text { Females } \\
\text { Character }\end{array}$} & \multicolumn{3}{|c|}{ Typical form $(n=92)$} & \multicolumn{3}{|c|}{ Small form $(n=56)$} & & \multirow{2}{*}{\multicolumn{2}{|c|}{$p$}} \\
\hline & Mean & $\mathrm{SD}$ & $\pm 95 \%$ & Mean & SD & $\pm 95 \%$ & $F$ & & \\
\hline Body length & 2.77 & 0.298 & $2.710-2.834$ & 1.83 & 0.166 & $1.787-1.876$ & 437.1 & $<0.00001$ & $* * *$ \\
\hline Body width & 0.98 & 0.087 & $0.967-1.003$ & 0.80 & 0.076 & $0.779-0.820$ & 177.5 & $<0.00001$ & $* * *$ \\
\hline Head length & 0.34 & 0.029 & $0.336-0.348$ & 0.34 & 0.032 & $0.334-0.351$ & 0.01 & 0.931 & ns \\
\hline Head width & 0.31 & 0.035 & $0.299-0.313$ & 0.28 & 0.036 & $0.270-0.289$ & 17.8 & 0.00004 & $* * *$ \\
\hline Pronotal comb length & 0.094 & 0.013 & $0.091-0.097$ & 0.088 & 0.014 & $0.084-0.092$ & 7.56 & 0.007 & $* *$ \\
\hline Pronotal comb height & 0.26 & 0.029 & $0.253-0.265$ & 0.24 & 0.027 & $0.232-0.246$ & 17.4 & 0.00005 & $* * *$ \\
\hline Tarsus III length & 0.87 & 0.073 & $0.856-0.887$ & 0.82 & 0.082 & $0.800-0.844$ & 14.7 & 0.0002 & $* * *$ \\
\hline Thorax length & 0.49 & 0.069 & $0.471-0.500$ & 0.39 & 0.057 & $0.377-0.408$ & 67.5 & $<0.00001$ & $* * *$ \\
\hline Abdomen length & 1.91 & 0.214 & $1.861-1.950$ & 1.07 & 0.122 & $1.041-1.106$ & 621.7 & $<0.00001$ & $* * *$ \\
\hline
\end{tabular}

$S D$ standard deviation, $\pm 95 \%$ confidence interval

$p$ statistical significance $\left({ }^{*} p<0.05,{ }^{*} p<0.01, * * * p 0.001\right)$, ns not significant 
of highly orchestrated development of different body parts and organs in holometabolous insects developing under different food qualities [40, 41]. However, if the variation in food resource is highly unpredictable, such adaptive plasticity is less likely to evolve [42]. Thus, adaptive intraspecific allometry of life span and reproduction is expected, when variation in body size is genetic or environmentally induced, as long as there are reliable cues to be used enabling the organism to predict the variation in food resource, but to less extent when variation in growth conditions is unpredictable [43].

The comparison of body size showed that the examined forms in the population mostly differ in length of abdomen, whereas length of head and tarsus III were less variable. Similar results found Blaski et al. [9] analyzing seasonal morphological variability of $C$. gallinae parasitized blue tits. That study also highlights the presence of two groups among male and female life forms. The occurrence of two morphologically different adult forms in other species from Siphonaptera is still not found, therefore the hen flea is the only known species, which showed a peculiar type of morphological diversity $[9,25,34]$. In our study, two different flea morphotypes occurred together in the same nest boxes, regardless of the season when they were collected.

Males and females of fleas, which parasitize on the same hosts and share the same alimentary niche, undergo natural selection [22]. If the primary host spends most of the time in the nest, like in case of $C$. caeruleus the variability of environmental conditions is more observable. Moreover, the differences in morphology among individuals of one flea species can depend on microhabitat, where larval development occurs and adult forms exist [28]. In 1999, Tripet and Richner [34] were modulating natural conditions in blue tits nests and analyzed the dynamics of hen fleas in order to check their interactions. During one birds' nestling cycle, they observed presence of two different adult forms and named them as subpopulations. In regards to the fact, that the examined material in this study came from identical nest boxes and the conditions were not modulated, we can assume that physiochemical conditions were very similar. Thus we could imply our results to a foregoing study. There are suggestions about the existence of local adaptation between hen fleas and great tits [44]. It based on observation of reproductive success $C$. gallinae, which at the end of tits breeding was higher for foreign than local fleas. It could be parasite local maladaptation, but on the other hand, reproductive success of great tits was lower for nests infested by foreign fleas in comparison to the control (nests infested by local fleas in an intermediate position) [44].

In general, bimodal variance of body size is rarely encountered, and even unparallel in case of sexual dimorphism. This phenomenon among one species is often a basis to separation of a taxon, but sometimes like in the study from
2013 by Balvin et al. [19], two of those forms were found genetically identical (Cimicidae). The mentioned study showed that populations of haematophagous ectoparasitesCimex pipistrelli Jenyns, 1839 bat bugs were morphologically differentiated between host species, but that variability was not supported by nuclear and mitochondrial DNA [19].

In conclusion, the only certain information is the presence of two adult life forms of $C$. gallinae. We know that development of two adult forms of this species is probably not dependent on the type of host or season [9]. The genesis of their creation is still unknown and we are not able to identify the mechanism responsible for the morphological differentiation of fleas collected from the same host. In order to find the answer to this question, future research in the field of molecular taxonomy is required. Presences of two morphologically different adult forms in other species from the order Siphonaptera until now were not found, therefore, C. gallinae is actually the only known species which showed a peculiar type of morphological diversity.

\section{Compliance with Ethical Standards}

Conflict of Interest The authors declare that they have no conflict of interest.

Ethical Approval This article does not contain any studies with human participants performed by any of the authors.

Open Access This article is licensed under a Creative Commons Attribution 4.0 International License, which permits use, sharing, adaptation, distribution and reproduction in any medium or format, as long as you give appropriate credit to the original author(s) and the source, provide a link to the Creative Commons licence, and indicate if changes were made. The images or other third party material in this article are included in the article's Creative Commons licence, unless indicated otherwise in a credit line to the material. If material is not included in the article's Creative Commons licence and your intended use is not permitted by statutory regulation or exceeds the permitted use, you will need to obtain permission directly from the copyright holder. To view a copy of this licence, visit http://creativecommons.org/licenses/by/4.0/.

\section{References}

1. Stillwell RC, Blanckenhorn WU, Teder T, Davidowitz G, Fox CW (2010) Sex differences in phenotypic plasticity affect variation in sexual size dimorphism in insects: from physiology to evolution. Annu Rev Entomol. https://doi.org/10.1146/annurev-ento-11240 8-085500

2. Andersson M (1994) Sexual selection. Monographs in behaviour and ecology. Princeton, Princeton University Press, p 599

3. Davidowitz G (2008) Population and environmental effects on the size-fecundity relationship in a common grasshopper across an aridity gradient. J Orthopt Res. https://doi. org/10.1665/1082-6467-17.2.265 
4. Fox CW, Stillwell RC, Wallin WG, Hitchcock LJ (2006) Temperature and host species affect nuptial gift size in a seed-feeding beetle. Funct Ecol. https://doi.org/10.1111/j.1365-2435.2006.01197 .x

5. Fox CW, Czesak ME (2000) Evolutionary ecology of progeny size in arthropods. Annu Rev Entomol. https://doi.org/10.1146/annur ev.ento.45.1.341

6. Honek A (1993) Intraspecific variation in body size and fecundity in insects: a general relationship. Oikos. https://doi. org/10.2307/3544943

7. Preziosi RF, Fairbairn DJ, Roff DA, Brennan JM (1996) Body size and fecundity in the waterstrider Aquarius remigis: a test of Darwin's fecundity advantage hypothesis. Oecologia. https://doi. org/10.1007/BF00333717

8. Teder T, Tammaru T (2004) Sexual size dimorphism within species increases with body size in insects. Oikos. https://doi.org/10 .1111/j.0030-1299.2005.13609.x

9. Blaski M, Kalimon H, Wojciechowski W (2005) Seasonal morphological variability of Ceratophyllus gallinae (SCHRANK, 1803) (Insecta, Siphonaptera). Acta Entomol Sil 12(13):5-17

10. Fain A, Guerin B, Hart BJ (1990) Mites and allergic disease. Allerbio, Varennes en Argonne, p 190

11. Evans GO (1992) Principles of Acarology. CAB International, Wallingford, $\mathrm{p} 563$

12. Vargas MV, Smiley RL (1994) A new species of Hughesiella (Acari: Astigmata, Pyroglyphidae) from Costa Rica. Int J Acarol. https://doi.org/10.1080/01647959408684011

13. Dabert M, Bigoś A, Witaliński W (2011) DNA barcoding reveals andropolymorphism in Aclerogamasus species (Acari: Parasitidae). Zootaxa. https://doi.org/10.11646/zootaxa.3015.1.2

14. Solarz K, Skubała P, Wauthy G, Szilman P (2016) Body size variability in different forms of heteromorphic males in populations of the house dust mite Dermatophagoides farinae Hughes 1961 (Acari: Astigmata: Pyroglyphidae). Annales Zoologici. https:// doi.org/10.3161/00034541ANZ2016.66.2.009

15. Nielsen MG, Watt WB (2000) Interference competition and sexual selection promote polymorphism in Colias (Lepidoptera Pieridae). Funct Ecol. https://doi.org/10.1046/j.1365-2435.2000.00472 . $\mathrm{x}$

16. Ellers J, Boggs CL (2003) The evolution of wing color: male mate choice opposes adaptive wing color divergence in Colias butterflies. Evolution. https://doi.org/10.1554/00143820(2003)057[1100:TEOWCM]2.0.CO;2

17. Svensson EI, Abbott JK, Gosden TP, Coreau A (2007) Female polymorphisms, sexual conflict and limits to speciation processes in animals. Evol Ecol. https://doi.org/10.1007/s10682-007-9208-2

18. Poulin R, Krasnov BR, Mouillot D (2009) Host specificity in phylogenetic and geographic space. Trends Parasitol. https://doi. org/10.1016/j.pt.2011.05.003

19. Balvin O, Vilimova J, Kratochvil L (2013) Batbugs (Cimex pipistrelli group, Heteroptera: Cimicidae) are morphologically, but not genetically differentiated among bat hosts. J Zoolog Syst Evol Res. https://doi.org/10.1111/jzs.12031

20. Tripet F, Jacot A, Richner H (2002) Larval competition affects the life histories and dispersal behavior of an avian ectoparasite. Ecology. https://doi.org/10.1890/0012-9658(2002)083[0935:LCATL $\mathrm{H}] 2.0 . \mathrm{CO} ; 2$

21. Johnson PTJ, Preston DL, Hoverman JT, Henderson JS, Paull SH, Richgels KLD, Redmond MD (2012) Species diversity reduces parasite infection through crossgenerational effects on host abundance. Ecology. https://doi.org/10.2307/23144021

22. Krasnov BR (2008) Functional and Evolutionary Ecology of Fleas, a Model for Ecological Parasitology. Cambridge University Press, New York, p 593 (ISBN: 978-0-521-88277-4)

23. Vatschenok VS (1988) Fleas-vectors of pathogens causing diseases in humans and animals. Nauka, Leningrad (in Russian)
24. Krasnov BR, Khokhlova IS, Fielden LF, Burdelova NV (2002) The effect of substrate on survival and development of two species of desert fleas (Siphonaptera: Pulicidae). Parasite. https://doi. org/10.1051/parasite/2002092135

25. Grzywacz B, Blaski M, Wojciechowski W (2005) Morphological variability of Ceratophyllus hirundinis (CURTIS, 1826), (Insecta, Siphonaptera). Acta entomologica silesiana 12-13:41-50

26. Skuratowicz W (1967) Part XXIX. Fleas - Siphonaptera (Aphaniptera). In: Key to classification of Polish insects, vol 53. Polish Entomological Society, Warsaw, pp 26-131

27. Titchener R (1980) Inhabitants of avian skin with special reference to ectoparasitic infestations and diseases of poultry skin. Proc $\mathrm{R}$ Soc Edinb. https://doi.org/10.1017/S0269727000010320

28. Tripet F, Richner H (1997) The coevolutionary potential of a 'generalist' parasite, the hen flea Ceratophyllus gallinae. Parasitology 115(4):419-427

29. Rothschild M, Clay T (1952) Fleas, flukes and cuckoos. A study of bird parasites. Collins, London (Record Number-19582201288)

30. Cotton MJ (1970) The life history of the Hen Flea, Ceratophyllus gallinae (Siphonaptera, Ceratophyllidae). Entomologist 103(1281):45-48

31. Harper GH, Marchant A, Boddington DG (1992) The ecology of the hen flea Ceratophyllus gallinae and moorhen flea Dasypsyllus gallinulae in nestboxes. J Anim Ecol. https://doi.org/10.2307/5324

32. Heeb P, Kölliker M, Richner H (2000) Bird-ectoparasite interactions, nest humidity, and ectoparasite community structure. Ecology. https://doi.org/10.2307/177170

33. Tomás G, Merino S, Moreno J, Morales J (2007) Consequences of nest reuse for parasite burden and female health and condition in blue tits Cyanistes caeruleus. Anim Behav. https://doi. org/10.1016/j.anbehav.2006.06.016

34. Tripet F, Richner H (1999) Dynamics of hen flea Ceratophyllus gallinae subpopulations in blue tit nests. J Insect Behav. https:// doi.org/10.1023/A:1020958615191

35. Krasnov BR, Burdelov SA, Khokhlova IS, Burdelova NV (2003) Sexual size dimorphism, morphological traits and jump performance in seven species of desert fleas (Siphonaptera). J Zool Lond. https://doi.org/10.1017/S0952836903004096

36. Suzuki R, Shimodaira H (2014) pvclust: hierarchial clustering with P-values via multiscale bootstrap resampling. https://cran.rproject.org/web/packages/pvclust/index.html.

37. R Development Core Team (2008) R: a language and environment for statistical computing. R Foundation for Statistical Computing, Vienna, Austria. https://www.R-project.org.

38. Stevens DJ, Hansell MH, Monaghan P (2000) Developmental trade-offs and life histories: strategic allocation of resources in caddis flies. Proc Biol Sci. https://doi.org/10.1098/rspb.2000.1172

39. Boggs CL (2009) Understanding insect life histories and senescence through a resource allocation lens. Funct Ecol. https://doi. org/10.1111/j.1365-2435.2009.01527.x

40. Shingleton AW, Frankino WA, Flatt T, Nijhout HF, Emlen DJ (2007) Size and shape: the developmental regulation of static allometry in insects. BioEssays. https://doi.org/10.1002/ bies. 20584

41. Tobler A, Nijhout HF (2010) Developmental constraints on the evolution of wing-body allometry in Manduca sexta. Evol Devel. https://doi.org/10.1111/j.1525-142X.2010.00444.x

42. DeWitt TJ, Sih A, Wilson DS (1998) Costs and limits of phenotypic plasticity. Trends Ecol Evol. https://doi.org/10.1016/S0169 -5347(97)01274-3

43. Berger D, Martinossi-Allibert I, Grieshop K, Lind MI, Maklakov AA, Arnqvist G (2016) Intralocus sexual conflict and the tragedy of the commons in seed beetles. Am Nat. https://doi. org/10.1086/687963 
44. Lemoine M, Doligez B, Richner H (2012) On the equivalence of host local adaptation and parasite maladaptation, an experimental test. Am Nat. https://doi.org/10.1086/663699
Publisher's Note Springer Nature remains neutral with regard to jurisdictional claims in published maps and institutional affiliations. 